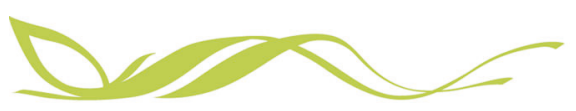

COMMUNICATIONS

ARTICLE

https://doi.org/10.1038/s43247-020-00069-4 OPEN

\title{
Near-complete loss of fire-resistant primary tropical forest cover in Sumatra and Kalimantan
}

Tadas Nikonovas (10 ${ }^{1 \times}$, Allan Spessa ${ }^{1}$, Stefan H. Doerr (1) ${ }^{1}$, Gareth D. Clay ${ }^{2}$ \& Symon Mezbahuddin (i) ${ }^{3}$

Deforestation in Indonesia in recent decades has made increasingly large parts of the region vulnerable to fires. Burning is particularly widespread in deforested peatlands, and it leads to globally significant carbon emissions. Here we use satellite-based observations to assess loss and fragmentation of primary forests and associated changes in fire regimes in Sumatra and Kalimantan between 2001 and 2019. We find that fires did not penetrate undisturbed primary forest areas deeper than two kilometres from the forest edge irrespective of drought conditions. However, fire-resistant forest now covers only $3 \%$ of peatlands and $4.5 \%$ of nonpeatlands; the majority of the remaining primary forests are severely fragmented or degraded due to proximity to the forest edge. We conclude that protection and regeneration of the remaining blocks of contiguous primary forest, as well as peatland restoration, are urgently needed to mitigate the impacts of potentially more frequent fire events under future global warming.

\footnotetext{
${ }^{1}$ Department of Geography, Swansea University, Singleton Park, Swansea SA2 8PP, UK. ${ }^{2}$ Department of Geography, School of Environment, Education and Development, University of Manchester, Oxford Road, Manchester M13 9PL, UK. ${ }^{3}$ Department of Renewable Resources, University of Alberta, Edmonton, AB T6G 2E3, Canada. ${ }^{凶}$ email: tadas.nik@gmail.com
} 
T he rates of commodity-driven loss and degradation of primary forests in Indonesia ${ }^{1,2}$ have been among the highest in the world over the past five decades ${ }^{3,4}$. The islands of Sumatra and Kalimantan, home to the majority of Indonesia's carbon-rich peatlands, have been particularly affected $^{5-7}$. One of the consequences of this rapid change in land use and cover has been a dramatic increase in fire occurrence. In recent decades, the region has experienced recurring extreme peatland burning episodes, most notably the $1997-1998^{8}$ and $2015^{9}$ events. These were globally significant greenhouse gas emission events and resulted in extended toxic haze episodes with severe effects on human health and the economy on local and regional scales ${ }^{10,11}$. The two interlinked phenomena of deforestation and peatland fires accounted for half ( 0.7 Gt of carbon) of the total annual carbon emissions in Indonesia in the 21st century and pose a challenge for the commitment of the Indonesian government to reduce emissions by at least $29 \%$ by $2030^{12}$. It is widely accepted that the ongoing tropical forest loss is exacerbating this challenge, because deforested land in this region is much more fire-prone ${ }^{13-15}$. However, a region-wide assessment of the ability of remaining primary forest to resist fire is currently lacking.

Fire is a rare phenomenon in intact tropical forest ecosystems ${ }^{13,16}$. Closed-canopy tropical forests limit the amount of solar radiation reaching the ground, maintain high humidity in the understorey, and lower temperatures by evaporative cooling on local scales ${ }^{17,18}$. Importantly, tropical forests are able to sustain elevated humidity during prolonged droughts ${ }^{19}$ and, as result, act as a protective layer shielding the landscape from the impacts of regional climate variability. While fires episodically did occur in Sumatra and Kalimantan during the Holocene ${ }^{20,21}$, they were infrequent and did not cause a long-term loss in the forest vegetation, which covered the majority of the region at least since the end of the Last Glacial Maximum ${ }^{3,16}$

Forest cover has played a particularly important role in the region's peatlands. An estimated $16-33 \mathrm{Gt}^{20,22}$ of carbon equivalent to 2-4 years' worth of contemporary global fossil fuel emissions - have accumulated in the region's peatlands since the Last Glacial Maximum, forming a peat layer up to 20 metres deep $^{23}$. These peatlands have been a persistent carbon sink for at least the last 20,000 years ${ }^{24}$, and in the late Holocene the region has been the most effective carbon sink on a unit area basis globally ${ }^{20}$. Throughout this time, forests were very effective at preventing this important carbon pool from being released into the atmosphere by fires through its regulating effect on climate at local and regional scales.

Reduction in tree canopy cover has a large effect on local and regional climate, and on surface energy balance ${ }^{25}$. Deforested landscapes in Sumatra and Kalimantan have a drier microclimate, experience more extreme temperature events and are substantially warmer ${ }^{26,27}$. Air temperature in selectively logged forests and oil palm plantations is on average up to $2.5^{\circ} \mathrm{C}$ and $6.5^{\circ} \mathrm{C}$ higher when compared to nearby undisturbed forests, respectively ${ }^{28}$. In peatlands, increased amounts of solar radiation due to reduced shading affects hydrology and accelerates desiccation and heating of nearsurface peat ${ }^{29}$, which has low thermal capacity and can be heated rapidly when dry. The increased fire risk is also exacerbated by widespread use of peatland drainage ${ }^{30}$, and the establishment of herbaceous and easily flammable vegetation in unmanaged land following forest clearing and recurrent burning ${ }^{31}$.

The effects of deforestation on susceptibility to fire are not limited to cleared land, but may extend up to several kilometres into adjacent undisturbed forests ${ }^{32,33}$. The resulting edge effects include increased tree mortality ${ }^{34}$, lowered tree reproduction rates $^{35}$, and lower biomass when compared to intact forests ${ }^{36,37}$. The fire risk at the forest edges is elevated by canopy desiccation ${ }^{38}$, increased temperature and wind ${ }^{39}$. Furthermore, in peatlands, artificial drainage can lower the water table up to $2 \mathrm{~km}$ into neighbouring peat swamp forest increasing peat ignitability 40,41 .

All the above factors, when coupled with extensive use of fire in human activities ${ }^{42}$, result in widespread burning on the converted land during dry periods ${ }^{43-45}$, which across the region are influenced by an intricate interplay of large-scale interannual climate variability modes. In south Sumatra and south Kalimantan, prolonged dry periods primarily occur during positive El Nino phase ${ }^{45,46}$, while positive Indian Ocean dipole (IOD) phase events have a greater influence on length and severity of dry season in north and central Sumatra ${ }^{47}$. The most severe drought episodes, like the 1997-98 event, occurred when both El Ninio and IOD were strongly positive. The region's peatlands are particularly affected, with many areas experiencing recurrent burning during the last three decades ${ }^{31,48}$. Repeated burning and oxidation of carbon due to drainage have therefore resulted in the region's peatlands converting from carbon sinks to sources ${ }^{49}$.

While the ongoing primary forest loss ${ }^{4,6}$ and associated increase in fire occurrence $5,14,46,50-52$ in Sumatra and Kalimantan have been highlighted previously, there are no region-wide assessments of the magnitude to which the region has been stripped of the drought and attendant fire protection that primary forests used to provide. Here we present an assessment of loss and fragmentation of primary forest cover combined with fire detections in peatland and non-peatland areas of Sumatra and Kalimantan within the last two decades (2001-2019), in order to identify trends and thresholds relevant to functioning of forests as a fire barrier and protection of peatland carbon stocks in the region. We find that undisturbed primary forest areas located at least $2 \mathrm{~km}$ from the forest edge are extremely resilient to fire, but only a small fraction of primary forests remain in this category. As a result, the magnitude of forest degradation and associated increase in high fire risk area is far greater than what the total extent of the remaining primary forests in the region would suggest.

\section{Results and discussion}

Changes in total primary forest extent. Primary forest cover in the Indonesian islands of Sumatra and Kalimantan (Fig. 1), both in the region's peatlands and non-peatlands reduced dramatically in extent between 2001 and 2019 (Fig. 2). At the beginning of year 2001, primary forests covered 45 Mha of the region's total area of 101.5 Mha, whereas at the end of 2018 the cover comprised only $37 \mathrm{Mha}$. This change equates to average annual primary forest loss of $0.43 \mathrm{Mha}$. Over half of the total loss occurred in nonpeatlands, where primary forest extent was reduced from $39 \mathrm{Mha}$ in 2000 to 33.6 Mha in 2019 (Fig. 2c). Relative change was much larger in peatlands, which cover approximately $11.4 \mathrm{Mha}(11 \%)$ of the region ${ }^{53}$ (see Methods). In the year 2000, primary forests covered $\sim 6$ Mha or $53 \%$ of peatlands. By the end of 2018 the extent was reduced to $3.4 \mathrm{Mha}$ (30\% of the area) (Fig. 2b).

During the study period, primary forest loss increased during the first half of the record, peaked in 2012 and gradually decreased afterwards. Notably, during the last two years in the record (2017 and 2018) deforestation has fallen to levels not seen since the 2001-2003 period (Fig. 2a). The overall reduction is primarily attributable to a large drop in primary forest loss in peatlands. This may be a sign that the policy changes and incentives in Indonesia such as the peatland restoration plan and moratoriums on primary forest clearing for oil palm plantations and logging operations ${ }^{54}$ have begun to improve the situation $^{55,56}$. As a result of this, Indonesia and Norway have agreed on a first payment as part of the Reducing Emissions from Deforestation and Forest Degradation (REDD + ) program ${ }^{57}$. 


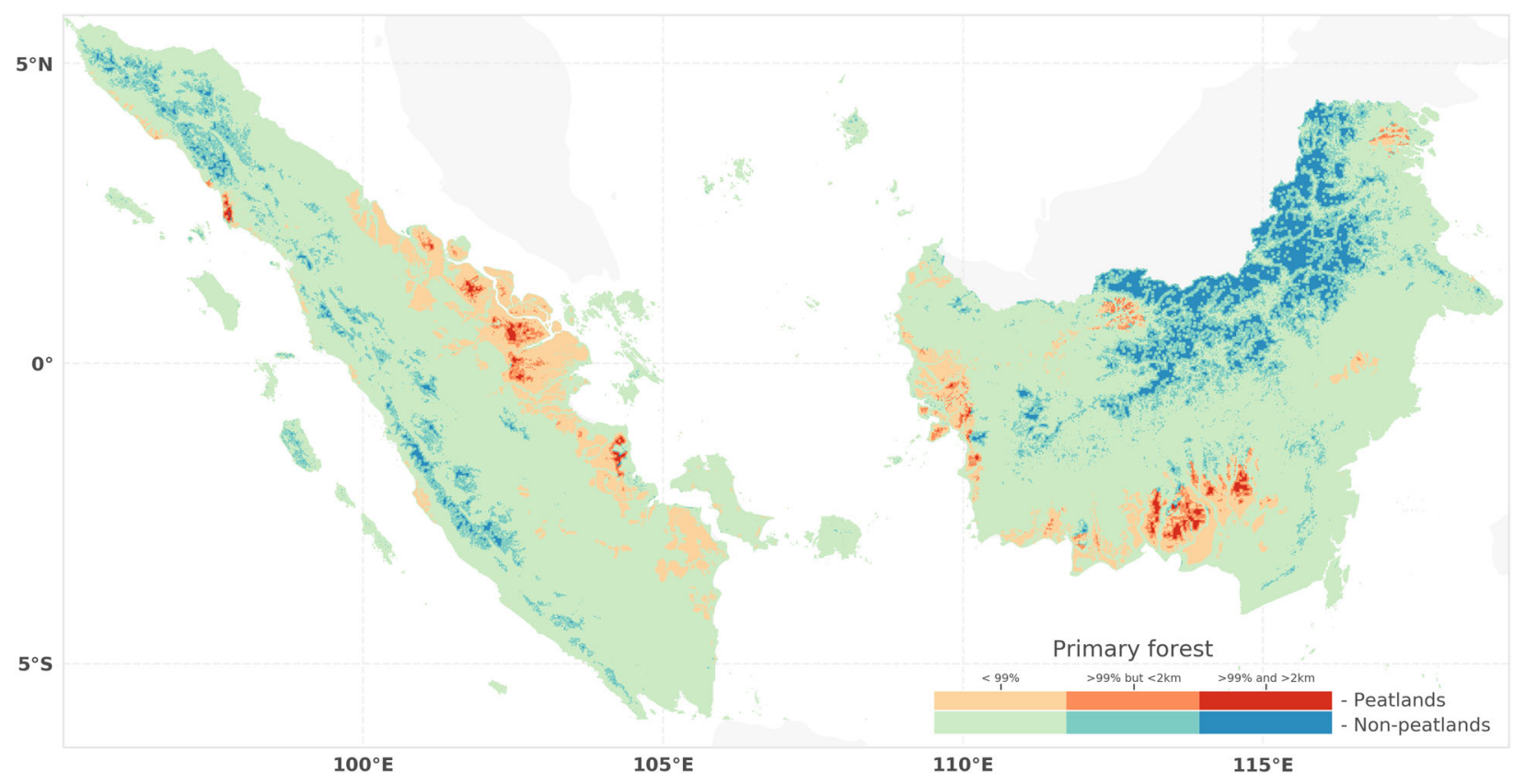

Fig. 1 The remaining fire-resilient primary forests in Sumatra and Kalimantan. Primary forest \% cover the region's peatlands (orange through red) and non-peatlands \% (green through blue) at the beginning of 2019. The categories shown are $<99 \%$ primary forest cover, primary forest cover $>99 \%$ but within $2 \mathrm{~km}$ from the forest edge, and primary forests cover $>99 \%$ and further than $2 \mathrm{~km}$ from the forest edge.

a) Primary forest loss in Sumatra and Kalimantan
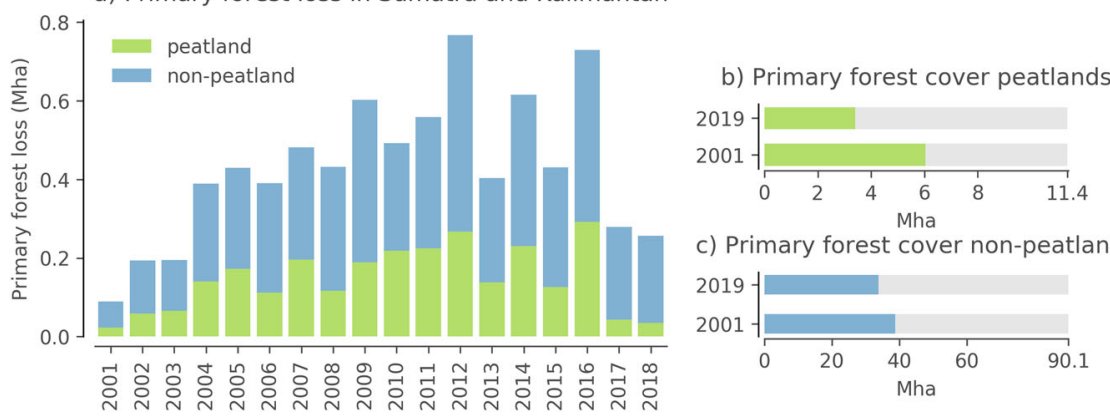

c) Primary forest cover non-peatlands

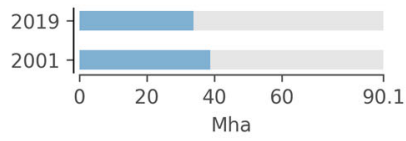

Fig. 2 Changes in total primary forest cover in Sumatra and Kalimantan from 2001 through 2018. a Annual primary forest cover loss in the region; and total primary forest cover at the beginning of 2001 and 2019 shown against total area of $\mathbf{b}$ peatlands and $\mathbf{c}$ non-peatlands.

Forest fragmentation. While estimates of total primary forest cover indicate a large reduction over the study period, these figures do not reveal the magnitude of degradation to structural integrity of the remaining forests. Our analysis of primary forest percent cover at $1 \mathrm{~km}$ resolution illustrates that the ecosystem is increasingly fragmented. The number of $1 \mathrm{~km}$ grid cells representing undisturbed primary forests, defined here as grid cells having primary forest cover of $99 \%$ or more, has reduced dramatically over the years (Fig. 3). The decrease was particularly strong in peatlands, where the area covered by undisturbed primary forest grid cells has reduced from approximately $32 \%$ of peatlands in 2000 to $16 \%$ at the end of 2018. Critically, this result shows that at the end of 2018 almost half of the remaining primary forests in peatlands were distributed either as small fragments and/or located close to the forest edge. A particularly large increase was recorded in area covered by mostly deforested grid cells $(50 \%$ to $1 \%$ cover), both in peatlands and non-peatlands. These dramatic changes have wide-ranging implications for biodiversity ${ }^{58,59}$, carbon storage ${ }^{37}$ and, indeed, fire occurrence in the region, as demonstrated below.
Primary forest cover and fire occurrence. When estimated for different primary forest cover percentage categories (Fig. 3), the fireaffected area (defined here as $\%$ of $1 \mathrm{~km}$ grid cells with active fire detections (see Methods)) was notably larger for areas with reduced or completely lost primary forest cover compared with relatively undisturbed closed-canopy forests. In the region's peatlands, fire affected on average only $0.9 \%$ of grid cells in the undisturbed primary forest category, but $6.2 \%$ of partially deforested, $11 \%$ of mostly deforested and $8.3 \%$ of completely deforested grid cells each year. In non-peatland areas, only $0.09 \%$ of undisturbed forest grid cells experienced fire each year, while fires were present in 1.3, 3.3 and $2.1 \%$ of the grid cells representing partially, mostly and completely deforested areas, respectively. In drought years, as much as $22 \%$ and $8 \%$ of the area was fire-affected in the most vulnerable, mostly and completely deforested categories in peatlands and non-peatlands, respectively. Meanwhile, in undisturbed forests the highest fireaffected area was $3 \%$ in peatlands and only $0.23 \%$ in non-peatlands (Fig. 3).

These results illustrate that once the microclimate regulation of the closed-canopy primary forests is lost, the many anthropogenic 

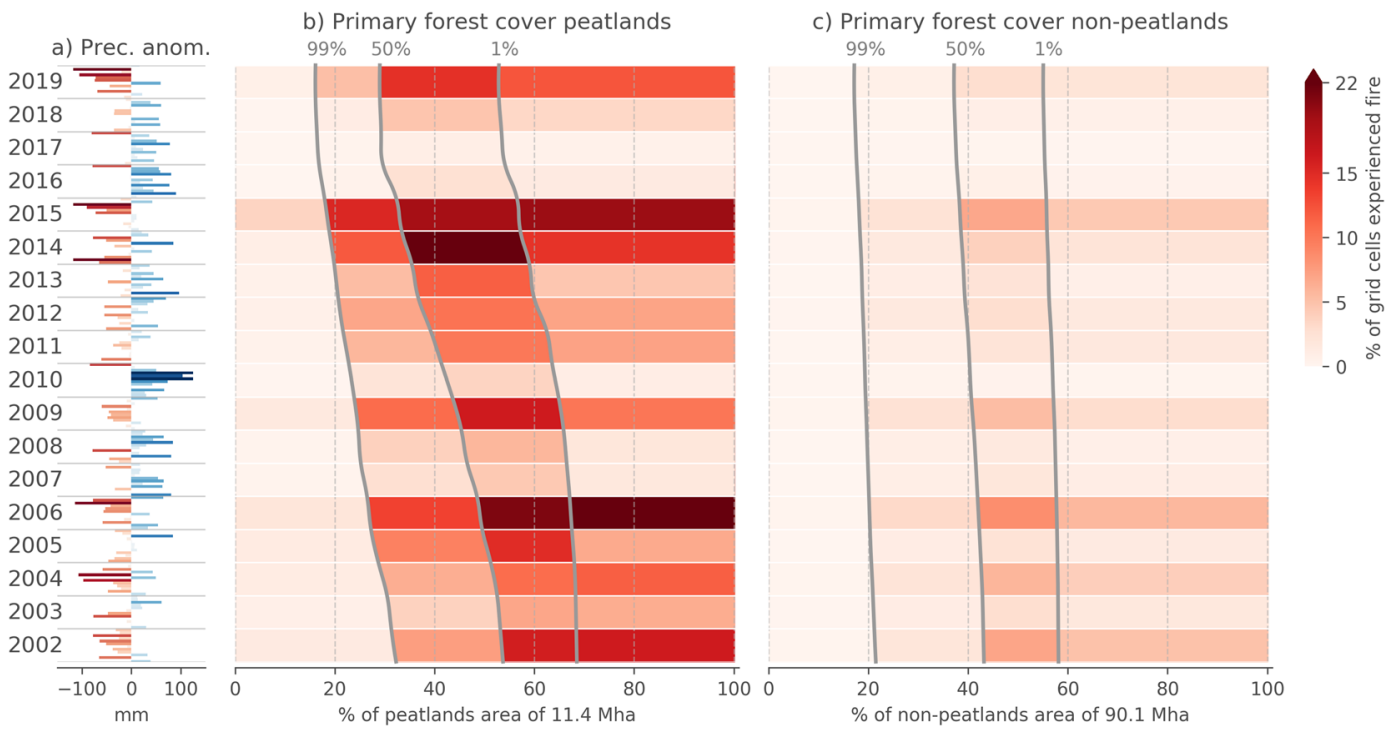

Fig. 3 Primary forest cover and fire occurrence in the region. a Monthly precipitation anomalies in the region for the study period (Methods). $\mathbf{b}, \mathbf{c}$ Change in extent and \% of fire-affected grid cells for different primary forest cover percent categories in peatlands (b) and non-peatlands (c) of Sumatra and Kalimantan. The grey lines represent primary forest cover thresholds and indicate year to year changes in extent of areas covered by $1 \mathrm{~km}$ grid cells having primary forest cover of more than $99 \%$ (area to the left from the $99 \%$ threshold line), $99 \%$ to $50 \%, 50 \%$ to $1 \%$ and less than $1 \%$. Colour indicates $\%$ of fire-affected grid cells. Primary forest cover estimates for each year represent the state at the beginning of the year. Forest loss estimate for that year is accounted for in the figure for the following year.

ignitions in the region ${ }^{42}$ often develop into persistent and large burning events during dry periods. The highest fire-affected area on mostly deforested land estimated in this study can be attributed to extensive use of fire as a tool for clearing the land for agriculture in the region $5,56,60$. The tool is very effective because highly fragmented and degraded patches of primary forests contain dead woody fuel and exhibit little ignitionresistance ${ }^{33}$ and as a result are easily ignited and consumed by both intentional burning or escaped fires.

Our results indicate that there is a long-lasting increase in fire risk in the deforested landscapes, extending beyond the immediate deforestation period. While areas with fragments of primary forests (between $50 \%$ and $1 \%$ cover) had the highest percentage of fire-affected grid cells, fire occurrences were nearly as high in land which has been completely deforested (less than $1 \%$ primary forest cover (Fig. 3)). Although deforestation fires are reduced once the land is fully cleared of primary forests, fire is still used in agricultural practices and as a means to prevent secondary regrowth ${ }^{52,60}$. Degraded and unmanaged peatlands in this region have therefore short fire return intervals and as a result such areas become dominated by flammable grasses and ferns and effectively switch to a stable treeless state ${ }^{14,31}$. While in some managed land cover types, such as large-scale oil palm and pulp plantations fire may be undesirable and is actively suppressed, such areas nonetheless have higher fire occurrence rates when compared to primary forests ${ }^{15}$.

Overall, the percentage of fire-affected grid cells in peatlands estimated in this study was on average 4.3 times higher when compared with non-peatlands. This signifies the vulnerability of deforested tropical peatland's carbon pool to fire emissions. In peatlands, the fire problem is exacerbated by drainage and desiccation of surface peat which makes it highly combustible ${ }^{14,48}$. Once ignited, the peat layer can sustain underground smouldering combustion for weeks and even months and spread over large area. As a result, the region's peatlands, while representing only $11 \%$ of the area, are the source of the majority of smoke emissions during the extreme fire episodes ${ }^{61}$.
The increase in fire-prone area over the study years presented in Fig. 3 elucidates how the ongoing primary forest loss has amplified the burning episodes over time. Figure 4, which shows changes in primary forest cover and fire-affected area only for the grid cells which were $99 \%$ forested at the beginning of 2002, illustrates this point further. During the study period, half of undisturbed and hence fire-resilient primary forests have been affected by deforestation and transitioned to fire-prone landscapes (Fig. 4b). Although in non-peatlands (Fig. 4c) loss of undisturbed forests since 2001 was smaller in relative terms, the effect was the same more than a ten-fold increase in the percentage of fire-affected grid cells in areas affected by deforestation. The same pattern was observed across different sub-regions of Sumatra and Kalimantan (Supplementary Figs. 1-4). The land which has become fire-prone contributed considerably towards the magnitude of the two most recent large fire episodes in the record. Indeed, $15 \%$ of total fireaffected area during the 2015 episode occurred on land which experienced deforestation since the year 2002, while the respective figure for the 2019 event is $17 \%$.

While fires overall were rare in grid cells with primary forest cover of more than $99 \%$, they were nonetheless present in undisturbed primary forests, in particular during the years with negative monthly precipitation anomalies (Fig. 3a). The analysis of grid cell distance from the forest edge and fire occurrence during the study period (Fig. 4) shows that primary forest grid cells located at the forest edge were much more likely to be affected by fire, and that the vast majority of burning did occur within the first $2 \mathrm{~km}$ from the forest edge. While approximately half of the remaining undisturbed forests were located within $1 \mathrm{~km}$ from the forest edge, they accounted for 94 and $97 \%$ of all fire-affected grid cells in peatlands and non-peatlands, respectively. The grid cells located between 1 and $2 \mathrm{~km}$ from the edge accounted for further 6 and 3\% of the total fire-affected area. Notably, undisturbed primary forests located further from the forest edge than $2 \mathrm{~km}$ accounted for less than $1 \%$ of total fireaffected area within the forests both in peatlands and nonpeatlands, with only a few grid cells experiencing burning during the study period. This demonstrates that the small amount of 
b) Primary forest $>99 \%$ in 2002 peatlands Distance from the edge Primary forest cover
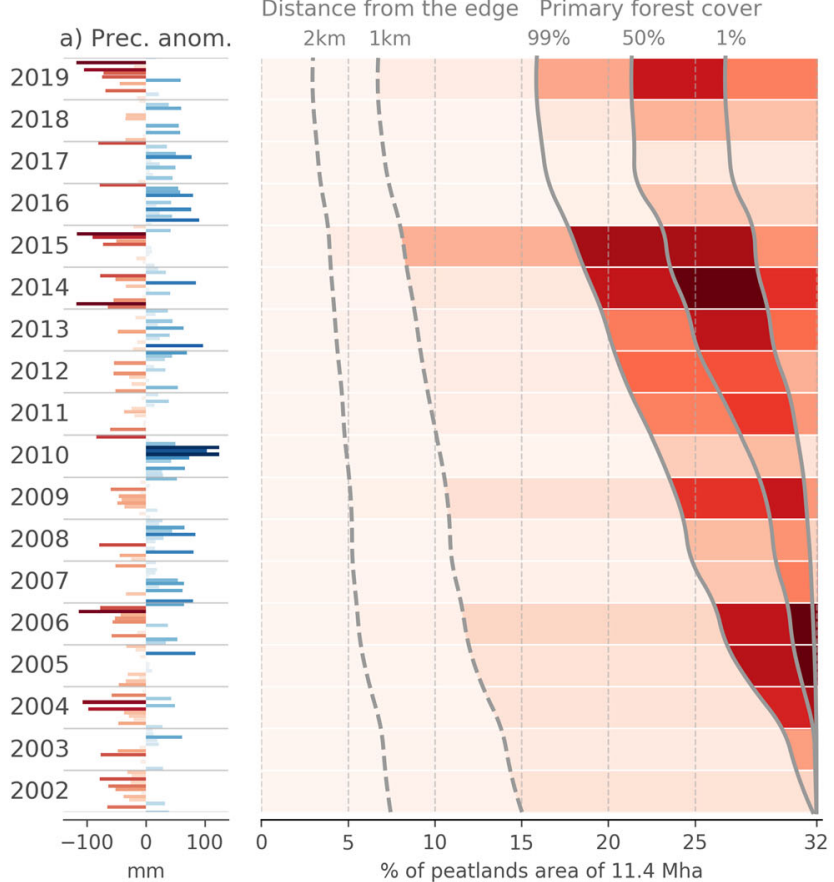

c) Primary forest $>99 \%$ in 2002 non-peatlands

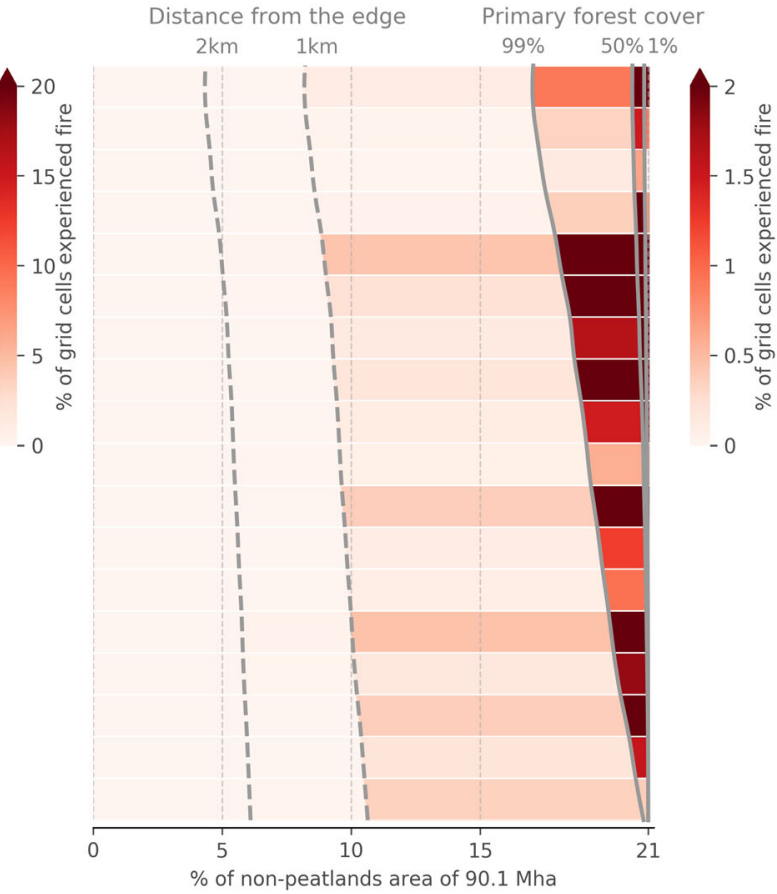

Fig. 4 Changes in forest cover and fire occurrence in areas which were $\mathbf{9 9 9 \%}$ primary forests in the year 2002. a Monthly precipitation anomalies in the region for the study period (Methods). b, c Change in extent and \% of fire-affected grid cells. In contrast to Fig. 3, this figure only shows $\mathbf{b}$ peatland and $\mathbf{c}$ non-peatland areas which were undisturbed primary forest (grid cells having $99 \%$ or more primary forest cover) at the beginning of year 2002 . Solid grey lines indicate the primary forest cover percentage thresholds as in Fig. 3. Dashed grey lines represent distance from the forest edge thresholds for the undisturbed forest category. Note different colour scales for peatland (b) and non-peatland (c) plots. See Supplementary Figs. 1-4 showing the same analysis split into different sub-regions of Sumatra and Kalimantan.

burning observed in the region's primary forests 15,46 was occurring within the first $2 \mathrm{~km}$ from the forest edge, while the inner regions remained virtually fire-free.

A near-absence of burning in the interior of the undisturbed primary forests yet again signifies how resilient to fire this ecosystem is and the role it plays in protecting millennia-aged peat carbon from combustion. The fact that this vanishingly small proportion of the remaining undisturbed forests did not ignite or permit persistent fires to burn into the inner regions (Fig. 4) indicates that in the 21 st century these forests were effectively decoupled from the impacts of regional climate variability on fire occurrence. The close association between climate and fire in the region ${ }^{43,45,51,62}$ does not seem to apply to primary forests which remain undisturbed and are not compromised by exposure to the edge effects. Extremely low numbers of fire-affected grid cells in such forests recorded during the study period suggests a very long fire return interval. This indicates that in the 21st century, as throughout the Holocene $e^{20,21}$, fire was not the main driver of deforestation in Sumatra and Kalimantan.

Notably, Fig. 4 also shows that at the end of 2018, undisturbed primary forests located further than $2 \mathrm{~km}$ from the edge comprised only $\sim 3 \%$ of the region's peatlands and $\sim 4.5 \%$ of non-peatlands area. Critically, up to $84 \%$ of the peatlands was under high fire risk (less than $99 \%$ primary forest cover, Fig. 3b) and an additional $13 \%$ was under increased fire risk (undisturbed primary forests within $2 \mathrm{~km}$ from forest edge, Fig. $4 \mathrm{~b}$ ). This result also means that only $10 \%$ of the remaining primary forests in peatlands in the year 2019 were in the 'resilient to fire' group, while the remaining $90 \%$ were either severely fragmented or degraded by the edge effects. During the study years, maximum distance from the forest edge reduced from 11 to $8 \mathrm{~km}$ in peatlands, and from 19 to $14 \mathrm{~km}$ in non-peatlands. The pace of disappearance of the forests which are not exposed to the edge effects in the region may mean that the first two decades of the 21st century provides the last opportunity to obtain satellitebased estimates of fire occurrence in undisturbed primary forests in Sumatra and Kalimantan.

The results demonstrate that the ongoing primary forest clearance in the region has led to substantial growth in the extent of the high fire-risk area, and in the region's carbon-rich peatlands in particular. While forest loss rates in peatlands and associated fires have been relatively low since 2017 , we estimate that only a small fraction of the remaining total area of primary forests in the region still function (as they did throughout the Holocene) as a 'layer' that protects the underlying peat from combustion. Of the peatlands in Sumatra and Kalimantan, 97\% have now transitioned from being fire-resilient to flammable due to a combination of widespread fragmentation, drainage and the replacement of fire-sensitive rainforest trees with pyrophillic invasive plant species such as ferns and grasses, with severe consequences for local communities, biodiversity, regional air quality and global climate.

\section{Methods}

Primary forest loss and extent. In this study, primary forest extent in the region for the year 2000 was determined from the primary forest cover dataset based on multi-temporal analysis of Landsat imagery 6,63 . In this product, all Landsat pixels $(\sim 25 \mathrm{~m} \times 25 \mathrm{~m})$ with tree height of at least $5 \mathrm{~m}$ and canopy cover of $>30 \%$ were considered as forest, and primary forest was defined as old-growth natural forest forming a contiguous block of at least 5 ha and which has not been deforested in recent history, including both intact and degraded types ${ }^{63}$. The product was shown to have $90.2 \%$ overall agreement ( $80 \%$ Kappa statistic) when compared to the primary forest map for the year 2000 of Ministry of Forestry of Indonesia ${ }^{6}$. In order to determine loss in primary forest cover in Sumatra and Kalimantan during the study period, we performed a co-located analysis of the primary forest cover of the year 2000 data $^{6}$ and a subset of the version 1.6 global annual forest cover loss 
dataset covering 2001 through $2018^{64}$. In this product, tree cover loss is defined as a stand replacement disturbance. Validation of tree cover loss for tropical regions suggests that forest loss was correctly identified in more than $80 \%$ of the cases (producer's accuracy $83.1 \%)^{64}$.

The analysis of primary forest loss was performed at the Landsat pixel level, replicating and extending in time the study of primary forest loss ${ }^{6}$. Tree cover loss pixels were matched with the primary forest cover dataset pixels to determine if loss was occurring in primary forest or in other tree cover areas. Total primary forest extent for each year was determined by subtracting accumulative primary forest loss leading to the year from primary forest extent in the year 2000. As a result, the derived primary forest cover estimate for a given year represents the state at the beginning of the year. Primary forest loss during that year is accounted for in the estimate for the year after.

The analysis of relationships between primary forest percentage cover and fire occurrences was performed at $1 \mathrm{~km}$ resolution. Individual primary forest $25 \mathrm{~m}$ pixels for each year were aggregated to derive per $0.01^{\circ}$ grid-cell primary forest percent cover. This study uses four different defined categories of primary forest percent cover. Grid cells were classified into one of four categories: 'undisturbed forest' (over $99 \%$ primary forest cover); 'partially deforested' $(50 \%<$ primary forest cover $<99 \%)$, 'mostly deforested $(1 \%<$ primary forest cover $<50 \%)$; and 'fully deforested' $(<1 \%$ primary forest cover). The $99 \%$ primary forest threshold in classifying undisturbed primary forests was used in order to allow for a small number of deforestation to occur within a $1 \mathrm{~km}$ grid cell (up to 16 out of $160025 \mathrm{~m}$ Landsat pixels in a $1 \mathrm{~km}$ grid cell) before it was reclassified as partially deforested. This was done to accommodate a small amount of natural canopy succession and/ or erroneous forest loss pixels. Correspondingly, a $1 \%$ primary forest threshold was used in defining fully deforested grid cells. While the selected $99 \%$ threshold caused the estimated extent of undisturbed primary forests to be approximately $20 \%$ larger when compared to a scenario when a strict $100 \%$ threshold was used, this only had a negligible effect on fire occurrence rates for the category. However, lowering the threshold further resulted in a large increase in fire detections in undisturbed primary forests, hence a $99 \%$ threshold was used.

Distance to the forest edge. Distance to the forest edge was computed for all undisturbed primary forest grid cells (cover $>99 \%$ ). For this purpose, any grid cells with less than $99 \%$ primary forest cover were considered to be non-forest. Distances were derived in a way that all primary forest grid cells adjacent to non-forest grid cells (8-connected neighbourhood) were classed as areas within $1 \mathrm{~km}$ from the edge.

Fire-affected areas. As a proxy for fire activity, the study used Moderate Resolution Imaging Spectroradiometer (MODIS) Collection 6 fire locations (MCD14ML) dataset, produced by the University of Maryland and provided by NASA Fire Information for Resource Management System. The product contains centre coordinates of MODIS pixels $\left(1 \mathrm{~km}^{2}\right.$ for areas directly below, up to $\sim 10 \mathrm{~km}^{2}$ in area at the extreme edges of the sensor view) flagged by the MODIS Thermal Anomalies algorithm ${ }^{65}$. The product has estimated $8 \%$ false detection rate for South Asia, and less than $10 \%$ omission error for fires of over $0.125 \mathrm{~km}^{2}$ globally ${ }^{65}$. To reduce the commission error further, low confidence $(<30 \%)$ detections were excluded from the analysis.

Fire-affected area was used as a proxy for fire activity. Using this approach, any $1 \mathrm{~km}$ grid-cells containing any number of active fire detections within any given year were flagged as fire-affected. In order to identify areas affected by large and persistent burning events, single active fire detections which were not part of bigger events were filtered out. This was achieved by agglomerating any individual active fires located closer than $3 \mathrm{~km}$ in space and less than $48 \mathrm{~h}$ in time. Following this step, only active fire detections which were part of fire events which were observed on at least two different days were selected for further analysis. This additional filtering step resulted in 12 and $45 \%$ reduction in total active fire detections in the region's peatlands and non-peatlands, respectively. The difference in reduction indicates that a larger proportion of active fire detections in non-peatlands is a record of small fires which do not develop into persistent burning events. This filtering step also brought the estimate of percentage of total fire-affected area attributable to peatlands up to $\sim 40 \%$, which is in the range of estimates obtained by other studies employing MODIS area-burned products and estimates based on different sensor data ${ }^{66}$.

Peatland areas. In order to differentiate between peatland and mineral soils (nonpeatland) areas the study utilized the high-resolution maps of Indonesian peat distribution and carbon content published by Wetlands International and Wildlife Habitat Canada ${ }^{53}$. The vector dataset was rasterized to $1 \mathrm{~km}$ resolution grid. Rasterization was applied in a way that any grid cells whose centre point was inside the peatlands polygons was considered to represent peatland areas. As a result, the total peatlands extent determined in this study is $~ 10 \%$ smaller than that derived directly from the source dataset.

Precipitation anomalies. This study used European Centre for Medium-Range Weather Forecasts (ECMWF) ERA5 $0.25^{\circ}$ global reanalysis precipitation dataset for deriving monthly precipitation anomalies in the region for the study period.
The anomalies shown in Figs. 3 and 4 represent difference between mean precipitation for all land ERA5 grid cells over Sumatra and Kalimantan for any given month and climatic monthly mean precipitation for the 2002-2019 period.

\section{Data availability}

All datasets used in the study are publicly available. Primary forest cover in year 2000 is available at: https://glad.umd.edu/dataset/primary-forest-cover-loss-indonesia-20002012. The annual forest loss data available on-line from: http://earthenginepartners. appspot.com/science-2013-global-forest. Active fire data can be downloaded from: https://firms.modaps.eosdis.nasa.gov/download. Peatland extent maps are available at: http://data.globalforestwatch.org/datasets. ERA5 reanalysis dataset can be downloaded from: https://climate.copernicus.eu/climate-reanalysis. The annual primary forest $\%$ cover and active fire detection counts at $1 \mathrm{~km}$ resolution datasets generated by this study can be accessed at https://doi.org/10.5281/zenodo.4199924.

Received: 6 May 2020; Accepted: 20 November 2020; Published online: 18 December 2020

\section{References}

1. Curtis, P. G., Slay, C. M., Harris, N. L., Tyukavina, A. \& Hansen, M. C. Classifying drivers of global forest loss. Science 361, 1108-1111 (2018).

2. Austin, K. G., Schwantes, A., Gu, Y. \& Kasibhatla, P. S. What causes deforestation in Indonesia? Environ. Res. Lett. 14, 024007 (2019).

3. Tsujino, R., Yumoto, T., Kitamura, S., Djamaluddin, I. \& Darnaedi, D. History of forest loss and degradation in Indonesia. Land use policy 57, 335-347 (2016).

4. Turubanova, S., Potapov, P. V., Tyukavina, A. \& Hansen, M. C. Ongoing primary forest loss in Brazil, Democratic Republic of the Congo, and Indonesia. Environ. Res. Lett. 13, 074028 (2018).

5. Miettinen, J., Hooijer, A., Wang, J., Shi, C. \& Liew, S. C. Peatland degradation and conversion sequences and interrelations in Sumatra. Reg. Environ. Change 12, 729-737 (2012).

6. Margono, B. A., Potapov, P. V., Turubanova, S., Stolle, F. \& Hansen, M. C. Primary forest cover loss in Indonesia over 2000-2012. Nat. Clim. Change 4, 730 (2014).

7. Stibig, H. J., Achard, F., Carboni, S., Rasi, R. \& Miettinen, J. Change in tropical forest cover of Southeast Asia from 1990 to 2010. Biogeosciences 11, 247-258 (2014).

8. Page, S. E. et al. The amount of carbon released from peat and forest fires in Indonesia during 1997. Nature 420, 61-65 (2002).

9. Huijnen, V. et al. Fire carbon emissions over maritime southeast Asia in 2015 largest since 1997. Sci. Rep. 6, 26886 (2016).

10. Koplitz, S. N. et al. Public health impacts of the severe haze in Equatorial Asia in September-October 2015: demonstration of a new framework for informing fire management strategies to reduce downwind smoke exposure Environ. Res. Lett. 11, 094023 (2016).

11. Crippa, P. et al. Population exposure to hazardous air quality due to the 2015 fires in Equatorial Asia. Sci. Rep. 6, 37074 (2016).

12. Wijaya, A. R. et al. How can Indonesia achieve its climate change mitigation goal? An analysis of potential emissions reductions from energy and land-use policies. World Resour. Inst. (Washington D.C, 2017).

13. Cochrane, M. A. Fire science for rainforests. Nature 421, 913 (2003).

14. Page, S. E. \& Hooijer, A. In the line of fire: the peatlands of Southeast Asia. Philos. Trans. Royal Soc. B 371, 20150176 (2016).

15. Miettinen, J., Shi, C. \& Liew, S. C. Fire distribution in Peninsular Malaysia, Sumatra and Borneo in 2015 with special emphasis on peatland fires. Environ. Manag. 60, 747-757 (2017)

16. Goldammer, J. G. History of equatorial vegetation fires and fire research in Southeast Asia before the 1997-98 episode: a reconstruction of creeping environmental changes. Mitig. Adapt. Strat. Glob. Chang. 12, 13-32 (2007).

17. Bonan, G. B. Forests and climate change: forcings, feedbacks, and the climate benefits of forests. Science 320, 1444-1449 (2008)

18. Baker, J. \& Spracklen, D. Climate benefits of intact Amazon forests and the biophysical consequences of disturbance. Front. For. Glob. Chang. 2, 47 (2019).

19. Uhl, C., Kauffman, J. B. and Cummings, D. L. Fire in the Venezuelan Amazon 2: environmental conditions necessary for forest fires in the evergreen rainforest of Venezuela. Oikos 53, 176-184 (1988).

20. Dommain, R., Couwenberg, J., Glaser, P. H., Joosten, H. \& Suryadiputra, I. N. $\mathrm{N}$. Carbon storage and release in Indonesian peatlands since the last deglaciation. Quat. Sci. Rev. 97, 1-32 (2014).

21. Cole, L. E. S., Bhagwat, S. A. \& Willis, K. J. Fire in the swamp forest: palaeoecological insights into natural and human-induced burning in intact tropical peatlands. Front. For. Glob. Chang. 2, 48 (2019). 
22. Warren, M., Hergoualc'h, K., Kauffman, J. B., Murdiyarso, D. \& Kolka, R. An appraisal of Indonesia's immense peat carbon stock using national peatland maps: uncertainties and potential losses from conversion. Carbon balanc. management 12, 12 (2017).

23. Page, S. E., Rieley, J. O. \& Banks, C. J. Global and regional importance of the tropical peatland carbon pool. Glob. chang. biol. 17, 798-818 (2011).

24. Page, S. E. et al. A record of late pleistocene and holocene carbon accumulation and climate change from an equatorial peat bog (Kalimantan, Indonesia): implications for past, present and future carbon dynamics. J. Quat. Sci. 19, 625-635 (2004).

25. Schultz, N. M., Lawrence, P. J. \& Lee, X. Global satellite data highlights the diurnal asymmetry of the surface temperature response to deforestation. J. Geophys. Res. 122, 903-917 (2017).

26. Sabajo, C. R. et al. Expansion of oil palm and other cash crops causes an increase of the land surface temperature in the Jambi province in Indonesia. Biogeosciences 14, 4619-4635 (2017).

27. McAlpine, C. A. et al. Forest loss and Borneo's climate. Environ. Res. Lett. 13, 044009 (2018).

28. Hardwick, S. R. et al. The relationship between leaf area index and microclimate in tropical forest and oil palm plantation: forest disturbance drives changes in microclimate. Agric. For. Meteorol. 201, 187-195 (2015).

29. Jauhiainen, J., Kerojoki, O., Silvennoinen, H., Limin, S. \& Vasander, H. Heterotrophic respiration in drained tropical peat is greatly affected by temperature-a passive ecosystem cooling experiment. Environ. Res. Lett. 9 , 105013 (2014).

30. Miettinen, J., Shi, C. \& Liew, S. C. Land cover distribution in the peatlands of Peninsular Malaysia, Sumatra and Borneo in 2015 with changes since 1990. Glob. Ecol. Conserv. 6, 67-78 (2016).

31. Hoscilo, A., Page, S. E., Tansey, K. J. \& Rieley, J. O. Effect of repeated fires on land-cover change on peatland in southern Central Kalimantan, Indonesia, from 1973 to 2005. Int. J. Wildland Fire 20, 578-588 (2011).

32. Laurance, W. F. Do edge effects occur over large spatial scales? Trends Ecol. Evol. 15, 134-135 (2000).

33. Cochrane, M. A. \& Laurance, W. F. Fire as a large-scale edge effect in Amazonian forests. J. Tropi. Ecol. 18, 311-325 (2002).

34. Laurance, W. F., Laurance, S. G. \& Delamonica, P. Tropical forest fragmentation and greenhouse gas emissions. For. Ecol. Manag. 110, 173-180 (1998).

35. Curran, L. M. et al. Impact of El Nino and logging on canopy tree recruitment in Borneo. Science 286, 2184-2188 (1999).

36. Chaplin-Kramer, R. et al. Degradation in carbon stocks near tropical forest edges. Nat. Commun. 6, 10158 (2015).

37. Brinck, K. et al. High resolution analysis of tropical forest fragmentation and its impact on the global carbon cycle. Nat. Commun. 8, 1-6 (2017).

38. Briant, G., Gond, V. \& Laurance, S. G. Habitat fragmentation and the desiccation of forest canopies: a case study from eastern Amazonia. Biol. conserv. 143, 2763-2769 (2010).

39. Didham, R. K. \& Lawton, J. H. Edge structure determines the magnitude of changes in microclimate and vegetation structure in tropical forest fragments. Biotropica 31, 17-30 (1999).

40. Hooijer, A. et al. Subsidence and carbon loss in drained tropical peatlands. Biogeosciences 9, 1053 (2012).

41. Evans, C. D. et al. Rates and spatial variability of peat subsidence in Acacia plantation and forest landscapes in Sumatra, Indonesia. Geoderma 338 410-421 (2019).

42. Cattau, M. E. et al. Sources of anthropogenic fire ignitions on the peat-swamp landscape in Kalimantan, Indonesia. Glob. Environ. Chang. 39, 205-219 (2016).

43. Wooster, M. J., Perry, G. L. W. and Zoumas, A. Fire, drought and El Niño relationships on Borneo (Southeast Asia) in the pre-MODIS era (1980-2000). Biogeosciences 9, (2012)

44. Spessa, A. C. et al. Seasonal forecasting of fire over Kalimantan, Indonesia. Nat. Hazards Earth Syst. Sci. 15, 429-442 (2015).

45. Field, R. D. et al. Indonesian fire activity and smoke pollution in 2015 show persistent nonlinear sensitivity to El Niño-induced drought. Proc. Natl Acad. Sci. 113, 9204-9209 (2016)

46. Langner, A. \& Siegert, F. Spatiotemporal fire occurrence in Borneo over a period of 10 years. Glob. Chang. Biol. 15, 48-62 (2009).

47. Pan, X., Chin, M., Ichoku, C. M. \& Field, R. D. Connecting Indonesian fires and drought with the type of El Niño and phase of the Indian Ocean Dipole during 1979-2016. J. Geophys. Res. 123, 7974-7988 (2018).

48. Konecny, K. et al. Variable carbon losses from recurrent fires in drained tropical peatlands. Glob. Chang. Biol. 22, 1469-1480 (2016).

49. Miettinen, J., Hooijer, A., Vernimmen, R., Liew, S. C. \& Page, S. E. From carbon sink to carbon source: extensive peat oxidation in insular Southeast Asia since 1990. Environ. Res. Lett. 12, 024014 (2017).
50. Langner, A., Miettinen, J. \& Siegert, F. Land cover change 2002-2005 in Borneo and the role of fire derived from MODIS imagery. Glob. Chang. Biol. 13, 2329-2340 (2007)

51. van der Werf, G. R. et al. Climate regulation of fire emissions and deforestation in equatorial Asia. Proc. Natl Acad. Sci. 105, 20350-20355 (2008).

52. Tacconi, L. Preventing fires and haze in Southeast Asia. Nat. Clim. Chang. 6, 640 (2016).

53. Wahyunto, R. S. \& Suparto, S. H. Maps of area of peatland distribution and carbon content in Kalimantan, 2000-2002. Wetl. Int.-Indones. Program. Wildl. Habitat Can. (WHC) Bogor. (2004).

54. Purnomo A. Protecting Indonesia's Forests, Pros-Cons Policy of Moratorium on Forests and Peatlands (Kepustakaan Populer Gramedia, Jakarta, Indonesia, 2012).

55. Normile, D. Indonesia's fires are bad, but new measures prevented them from becoming worse. Sci. Mag. https://www.sciencemag.org/news/2019/10/ indonesias-fires-are-bad-new-measures-prevented-them-becoming-worse (2019).

56. Purnomo, H. et al. Fire economy and actor network of forest and land fires in Indonesia. For. Policy Econ. 78, 21-31 (2017).

57. Seymour, F. Indonesia Reduces Deforestation, Norway to Pay Up. World Resources Institute. https://www.wri.org/blog/2019/02/indonesia-reducesdeforestation-norway-pay (2019).

58. Haddad, N. M. et al. Habitat fragmentation and its lasting impact on Earth's ecosystems. Sci. Adv. 1, 1500052 (2015).

59. Watson, J. E. et al. The exceptional value of intact forest ecosystems. Nat. Ecol. Evol. 2, 599-610 (2018).

60. Gaveau, D. L. et al. Major atmospheric emissions from peat fires in Southeas Asia during non-drought years: evidence from the 2013 Sumatran fires. Sci. Rep. 4, 6112 (2014).

61. Wooster, M. et al. New tropical peatland gas and particulate emissions factors indicate 2015 Indonesian fires released far more particulate matter (but less methane) than current inventories imply. Remote Sens. 10, 495 (2018)

62. Taufik, M. et al. Amplification of wildfire area burnt by hydrological drought in the humid tropics. Nat. Clim. Chang. 7, 428-431 (2017).

63. Margono, B. A. et al. Mapping and monitoring deforestation and forest degradation in Sumatra (Indonesia) using Landsat time series data sets from 1990 to 2010. Environ. Res. Lett. 7, 034010 (2012).

64. Hansen, M. C. et al. High-resolution global maps of 21st-century forest cover change. Science 342, 850-853 (2013).

65. Giglio, L., Schroeder, W. \& Justice, C. O. The collection 6 MODIS active fire detection algorithm and fire products. Remote Sens. Environ. 178, 31-41 (2016).

66. Lohberger, S., Stängel, M., Atwood, E. C. \& Siegert, F. Spatial evaluation of Indonesia's 2015 fire-affected area and estimated carbon emissions using Sentinel-1. Glob. Chang. Biol. 24, 644-654 (2015).

\section{Acknowledgements}

This study forms part of the Towards a Fire Early Warning System for Indonesia (ToFEWSI) project, which is funded through the UK's National Environment Research Council - Newton Fund on behalf of UK Research \& Innovation (NE/P014801/1) and Indonesia Endowment Fund for Education and the Indonesian Science Fund.

\section{Author contributions}

T.N. and A.S. designed the study with input from S.H.D. T.N. performed the analyses and wrote the initial paper. A.C.S, S.H.D., G.D.C. and S.M. contributed to interpreting the results and writing the final paper.

\section{Competing interests}

The authors declare no competing interests.

\section{Additional information}

Supplementary information is available for this paper at https://doi.org/10.1038/s43247 020-00069-4.

Correspondence and requests for materials should be addressed to T.N.

Peer review information Primary handling editor: Joe Aslin.

Reprints and permission information is available at http://www.nature.com/reprints

Publisher's note Springer Nature remains neutral with regard to jurisdictional claims in published maps and institutional affiliations. 
(c) (i) Open Access This article is licensed under a Creative Commons Attribution 4.0 International License, which permits use, sharing, adaptation, distribution and reproduction in any medium or format, as long as you give appropriate credit to the original author(s) and the source, provide a link to the Creative Commons license, and indicate if changes were made. The images or other third party material in this article are included in the article's Creative Commons license, unless indicated otherwise in a credit line to the material. If material is not included in the article's Creative Commons license and your intended use is not permitted by statutory regulation or exceeds the permitted use, you will need to obtain permission directly from the copyright holder. To view a copy of this license, visit http://creativecommons.org/ licenses/by/4.0/.

(C) The Author(s) 2020 